\title{
Tension between visibility and invisibility: Science communication in new information environments
}

\author{
Julia Metag, University of Münster, Department of Communication, Germany \\ Julia.metag@uni-muenster.de
}

\begin{abstract}
The visibility and invisibility of scientific knowledge, its creation, and of scientists are at the core of science communication research. Thus, prominent paradigms, such as the public understanding of science or public engagement with science and technology, have implications for the visibility of scientific knowledge in the scientific community and among the public. This article posits that visibility in science communication is achieved with the availability of scientific knowledge, the approval of its dissemination, and its accessibility to third parties. The public understanding of science and public engagement with science paradigms emphasize different aspects of visibility with the latter focusing on the visibility of the creation of scientific knowledge more than public understanding of science which focuses on the knowledge itself. The digital information environment has engendered new formats and possibilities for visibility but also new risks, thereby creating tensions in science communication.
\end{abstract}

\section{Keywords}

open science, public engagement, science communication, social media, visibility

\section{Introduction}

Science communication has been studied under several well-known paradigms, from the deficit model to the public understanding of science (PUS) and the public engagement with science and technology (PEST) models (Bucchi, 2008). The public visibility of science, scientific knowledge, and of scientists are at the core of each paradigm. It has been argued that science needs to be visible not only to scientists but also to lay audiences to gain legitimacy, enhance knowledge, promote positive attitudes, and increase engagement (Bucchi, 2008). The advent of online communication has exponentially increased possibilities for the visibility of science (Brossard, 2013). Scientists can become more visible to the broader public through social media, and the public can follow "science in the making" online. Thus, aspects of the scientific process that had previously been invisible to the public have become accessible (Schäfer, 2017b). The concept of visibility is also at the forefront of the open science movement, which advocates for transparency, openness, and reproducibility. Examples are open-access publishing (i.e., making knowledge freely available to the public), open data (i.e., making research data freely available), and freely available tools for collaboration (Fecher \& Friesike, 2014; Klein et al., 2018; Nosek et al., 2015).

However, many scholars have been critical of visibility in science communication. While a majority of scientists are open to collaborating with journalists and believe in the need for the public communication of science, studies have demonstrated that journalists and scientists often have competing goals. For example, scientists believe that they should be able to influence news coverage, and journalists naturally strive for independence (Peters, 2019). Opinions on the visibility of science and scientists are even more divergent in the new information environment (Donk, 2011; Schäfer, 2017b). Some scientists are hesitant to communicate online or through social media because they consider it a distraction from their work (Neuberger, 2014). In addition, scientists are concerned that information can be manipulated or misused (Scheufele \& Krause, 
2019) or that their reputations in the scientific community could suffer from being too visible online (Dernbach, 2012; Wenninger, Weingart, \& Wormer, 2017). Thus, the internet has created considerable tension between visibility and invisibility in science communication.

This article utilizes a theoretical perspective to discuss this tension. It first examines the concepts of visibility and invisibility in science communication with a focus on scientists and scientific knowledge. Second, it discusses the prominent theoretical paradigms and their implications for visibility and invisibility. Third, drawing on the research on science communication in new information environments, it outlines the tensions engendered by online media and the management of these tensions by scientists and journalists.

\section{Visibility in science communication}

In order to approach the concept of visibility in science communication, we will first present theoretical concepts of visibility and then, based on these approaches, discuss conceptualizations of the visibility of scientific knowledge and of scientists.

\subsection{The concept of visibility}

Visibility in science communication can encompass the visibility of scientific knowledge and the visibility of scientists. Thus, conceptualizations of visibility that deal with the visibility of information and content as well as those that deal with the visibility of actors are relevant.

The visibility of information, data, or content has been discussed over the last decades in the context of the societal relevance of information and communication technologies that increase the visibility of information and data (Flyverbom, Leonardi, Stohl, \& Stohl, 2016; Leonardi, 2014). In this paper, Stohl, Stohl, and Leonardi's (2016) definition is helpful: "Visibility is a construct consisting of three interrelated empirical attributes: (1) the availability of information, (2) approval to share information, and (3) the accessibility of information to third parties" (p. 125). Thus, information first needs to exist and be available (e.g., data must be recorded and stored). Second, approval is required for the storage, access, and use of data. Third, data access must be facilitated (e.g., directory knowledge, devices that meet the appropriate technological requirements, and the possession of the requisite technological skills must be available; Stohl et al., 2016). This paper therefore follows this definition and considers aspects of availability, approval, and accessibility when scientific knowledge is of concern.

When concerned with the visibility of actors, theoretical approaches utilized in political communication, public sphere theory, and organizational communication can be drawn on. Thompson (2005) addressed the relationship between visibility and power in his discussion on visibility in political communication and focused on politicians' use of mediated visibility to get elected and maintain power. Schaffer (2019) also hinted at the close connection between visibility and the issues of power and hierarchy. She showed that the term "visibility" refers to the power of self-assertion, being publicly present, and the forming of symbolic recognition (Schaffer, 2019, p. 2). Thus, visible actors, be they individuals or organizations, hold some form of power. This already connects to the idea that visibility is tied to the concept of the public sphere. As Dahlberg (2018) pointed out, the public sphere can be defined in terms of visibility through several facets, such as the notion that a disagreement must be visible - that is, it must be exposed to everyone it affects and also be recognized and understood (Dahlberg, 2018, p. 37). Further, "all individuals affected by a dispute should have equal possibility to see and be seen, hear and be heard, which entails equality of control over seeing and being seen, or hearing and being heard, or visibility" (Dahlberg, 2018, p. 38). As a consequence, the public sphere makes power structures visible. In this case, visibility means that the practices of powerful actors are exposed (Dahlberg, 2018).

Additionally, in organizational communication research, the concept of visi- 
bility has gained prominence (Cruz, 2017; Jonkman, Trilling, Verhoeven, \& Vliegenthart, 2020). Here, the notion of visibility ranges from an organization being identifiable and recognizable (Cruz, 2017; Scott, 2013) to the notion that it is part of the public discourse (e.g., it is covered in the media; Jonkman et al., 2020). This paper focuses on the visibility of scientists as actors and not on scientific organizations. When conceptualizing the visibility of scientists, we draw on the conceptualization of scientists' exposure to others, their identifiability, and the revelation of power structures in science.

\subsection{The visibility of scientific knowledge}

Against the background of Stohl et al.'s (2016) definition, the visibility of scientific knowledge needs to be assessed with regard to scientific knowledge's availability, approval by its creators, and accessibility. It addresses several facets, such as the visibility of the workings of science (i.e., journal articles or media coverage that make available and accessible scientific methods, procedures, and results). Generally, the visibility of knowledge content and the visibility of knowledge creation are distinguishable (Funck, 2015).

For example, the availability of new research findings on breast cancer can be discussed regarding the visibility of scientific knowledge. This requires the existence and storage of new research findings on breast cancer (e. g., in digital formats, as texts, or as visualizations; this constitutes the availability of information). Approval then needs to be granted for this information to be shared. The scientists must give their approval for the results to become visible through journal articles or agreements to make the data available (this constitutes approval to share information), and the data or texts need to be accessible to third parties. Other scientists must be able to read or to analyze the data on breast cancer (i.e., possession of the requisite software and knowledge). Likewise, the public must be able to access the journal in which the results are published (this constitutes the accessibility of information). The criteria of availability, approval, and accessi- bility are equally important in the visibility of scientific knowledge's creation. In this example, information about the theories, methods, and data analysis that are used in breast cancer research need to be available, approved, and accessible. The visibility of scientific knowledge's creation has become even more important in the recent debate on open science (Bowman \& Keene, 2018; Open Science Collaboration, 2015), which this paper addresses in its discussion on visibility in the new information environment.

The above examples point to another important aspect of the visibility of scientific knowledge: whether visibility refers to visibility in the scientific system and scientific community or to visibility to the broader public (Neuberger, 2014, p. 337). The differentiation between visibility in the scientific system and visibility to the public is also reflected in various forms of science communication. Science communication comprises the formal and informal communication among scientists as well as by scientists or scientific institutions to the public, and it includes communication about science in the public sphere (e.g., news coverage or the public use of scientific information; Bonfadelli et al., 2017). The availability, approval, and accessibility of scientific knowledge can have different meanings in the scientific system and the broader public. New research findings on breast cancer can be available to other scientists (e.g., through presentations at scientific conferences). Their visibility can be approved (e.g., through approval for other scientists to use the data), and the findings can be made accessible (e.g., through other scientists' knowledge and software with which the data are used). This kind of visibility is usually required within the scientific system because peer review is based on the need to make research findings available, approve their submission for review, and make them accessible to reviewers. The peer review system further highlights the relevance that scientific knowledge's creation is visible because reviewers must evaluate the research process (e.g., its theories and methods). 
However, visibility within the scientific system is not the same as visibility to the broader public. Although the general prerequisite of availability is met once scientific knowledge exists, approval and accessibility might not be granted to the broader public. Scientists might not approve of the public communication of their findings on breast cancer prior to peer review. Despite their approval of the public visibility of their findings, the findings might not be accessible to the general public. The public might lack the directory knowledge about the existing scientific information on breast cancer, the skills to interpret the data, or the substantial resources to do so (e.g., ability to pay for expensive scientific journals to access the research; Stohl et al., 2016). This creates an opportunity for science journalism. Indeed, providing directory knowledge, interpreting data, and reducing the effort the public must undertake to access scientific information are some of its core functions (Dunwoody, 2014).

\subsection{The visibility of scientists}

The visibility of scientists can be further distinguished as visibility in the scientific community and the public sphere. Thompson (2005) linked visibility to the sense of sight (cf. Schaffer, 2019). Thus, scientists are visible if they can be seen. This visibility was originally situational and reciprocal: an individual who is visible can be seen by other individuals and can also see them (Thompson, 2005). However, this approach limits the notion of visibility in science communication because such visibility often refers to a scientist being known within the scientific community. Visibility in this case is related to a scientist's reputation. Reputation is a form of perception that is based on the evaluation of former performances (Eisenegger, 2005; Vogler \& Post, 2019). Thus, it does not equal visibility because visibility, in a narrow sense, does not include this evaluative dimension. A scientist's reputation is rooted in two interconnected concepts: (i) collaboration and (ii) publications and citations (Petersen et al., 2014). Collaborations and connections to the scientific community provide scientists with visibility, at least within their fields or disciplines, but this does not necessarily mean that they are literally seen by other scientists, though they may benefit from awareness. Visibility in the scientific community is thus, at least regarding publications, detached from a physical presence. Rather, it is connected to being known in the scientific system. It results in a scientist having a good reputation because peer-reviewed publications and the fact that other scientists collaborate with said scientist signifies that their work has been given some approval; otherwise, it would not have been published.

Neuberger $(2014$, p. 337) differentiated between the scientific and general public spheres. In the academic or scientific sphere, scientists are usually visible only to other scientists and the students they educate. With media coverage, they become visible to the general public. When their visibility is analyzed from a communication or social science perspective, the focus is on to what extent and how they are covered by the media. In most studies on visibility in science communication, a visible scientist is one who has media visibility (Brantner \& Huber, 2013; Lehmkuhl \& Leidecker-Sandmann, 2019; Peters, 2013; Rödder, 2014). Thus, Thompson's (2005) perspective on reciprocity is no longer applicable to traditional mass media because scientists who are visible on television do not see their audiences. Mediated visibility means that scientists could become visible to audiences over large distances with little or no delay (Thompson, 2005).

In legacy media coverage, scientists' visibility is influenced by several factors: reputation, resources, and communication skills (Rödder, 2014). Hence, reputation is necessary for visibility not only to the scientific community but also the wider public. Highly esteemed scientists are more likely to be contacted by journalists and receive mass media coverage (Jensen, 2011; Peters, 2013; Rödder, 2014). Scientists expect colleagues with strong reputations to have a media presence (Felt \& Fochler, 2012). Those with more media outreach resources are also more likely 
to receive coverage. Institutional support, such as a press office, facilitates the integration of public outreach into scientists' daily work (Rödder, 2014). Finally, scientists' media visibility can be increased if they are willing and able to contact or be contacted by journalists and adapt to media logic (Peters, 2013; Rödder, 2014).

In theoretical works on visibility, the relationship between visibility and power and hierarchy is often discussed (Schaffer, 2019; Thompson, 2005). In science communication, knowledge is the main criterion, not power. The ideas related to visibility in political communication (e.g., Thompson, 2005) are not completely transferrable to science communication. However, some concepts are relevant. Scientists are usually visible in the public sphere when they accept invitations to be subject matter experts (Grundmann, 2017; Huber, 2014; Nölleke, 2013). Thus, their main avenue for gaining public attention is their knowledge or expertise. However, adding their expertise to the public discourse is not their only communication goal. As Horst (2013) asserted, scientists represent science to the public in several ways: as experts but also as research managers and guardians of science. Their role as research managers relates to their managerial role in academics. As guardians of science, they focus on the meaning of their research to citizens and the role of their communication in improving the public's understanding of science.

Thompson (2005) painted a dark picture of the results of politicians' inability to achieve mediated visibility: "But equally, the inability to achieve visibility through the media can confine one to obscurity and, in the worst cases, can lead to a kind of death by neglect" (p. 49). This problem of invisibility is not completely transferrable to science communication. Scientists value their visibility in the scientific system; this, however, can sometimes conflict with their public visibility. Therefore, public invisibility does not necessarily mean neglect - at least, not in the scientific system. Indeed, most scientists who are highly regarded as leading experts in their fields are not visible to the general public
(Rödder, 2014). On the contrary, being too visible in the media can be deemed problematic. Scientists fear a loss of reputation in the scientific community because colleagues can view a media presence as unscientific (Dernbach, 2012).

Even though the scientific system relies on knowledge as its guiding term, the notion of power related to visibility in the public and the scientific system also needs to be discussed. Regarding politicians, Thompson (2005, p. 49) stated: “To achieve visibility through the media is to gain a kind of presence or recognition in the public space, which can help to call attention to one's situation or to advance one's cause" (p. 49). Equally, public visibility through media coverage can attract attention to the results and social implications of scientists' studies. Bourguignon (2017) and Rödder (2014) found that for scientists, public visibility is combined with the hope of increasing their chances to acquire grants and thus strengthen their position within the scientific system. Indeed, scientists who are visible tend to become even more visible (Merton, 1968) and, thus, more powerful in science. At the very least, that some scientists strive for public visibility with the underlying hope that it will lead to power in the scientific system cannot be ruled out.

Figure 1 summarizes the most important theoretical differentiations regarding visibility in science communication. It illustrates the visibility of scientists and scientific knowledge. Regarding scientific knowledge, it also distinguishes between the visibility of scientific content and knowledge creation (i.e., the scientific process). The visibility of scientists, content of scientific knowledge, and knowledge creation can be further differentiated on the basis of their visibility within the scientific system or to the general public. 
Figure 1: Visibility of scientists and scientific knowledge

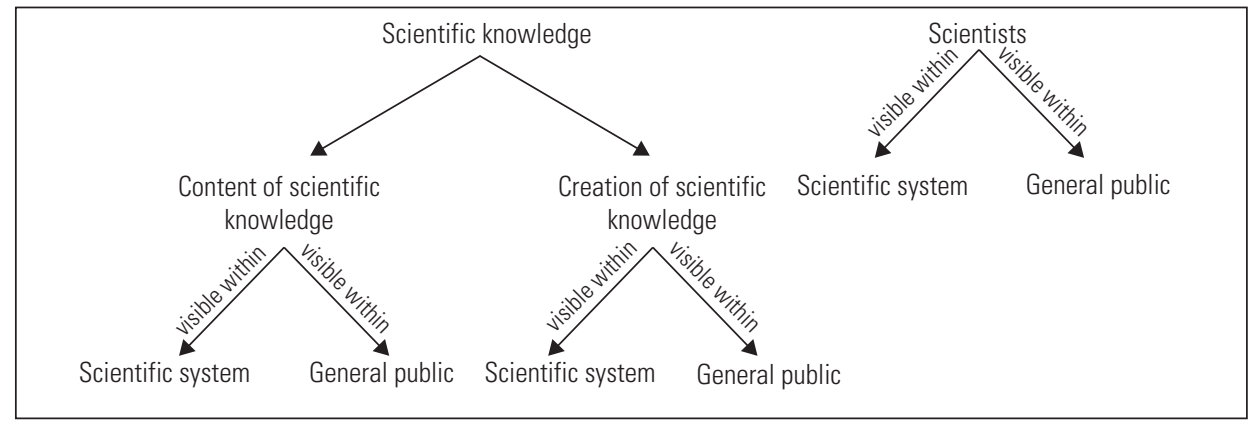

\section{3 (In)visibility, the public under- standing of science, and public engagement with science and technology paradigms}

The histories of science communication and its related models are most commonly divided into different phases: science in the ivory tower, PUS or the popularization of science, and PEST (Gerhards \& Schäfer, 2009; Schäfer, Kristiansen, \& Bonfadelli, 2015). During the ivory tower phase from the $18^{\text {th }}$ century to the mid- $20^{\text {th }}$ century, communication with the broader public was not important (Felt, 2000); however, scientists' reputation in the scientific community was. Thus, visibility was confined largely to the scientific system. It was achieved through formal and informal communication among its members (e.g., publications, collaborations, meetings, and conferences).

Around the 1980s, the popularization of science and the concept of the public's understanding of science became the main paradigms for science communication (Durant, 2010; Miller, 1983). The scientific community placed more emphasis on science communication because of the general public's lack of interest in and, thus, support for science. The PUS paradigm assumed that the mere enhancement of scientists' and scientific institutions' communicative activities was sufficient to improve the public's scientific literacy (Miller, 1983) and, thus, its support for and positive attitudes toward science
(Durant, 2010; Felt, 2000). It was assumed that news coverage would convey scientific information to the broader public and that journalists would uncritically explain scientific findings.

Visibility thus played a more important role in the PUS paradigm. It is understood as science, scientific knowledge, and scientists' visibility in the mass media (with the intention to foster positive public attitudes). Therefore, the presence of scientists as experts in the news media and the coverage of scientific results that were selected, simplified, and aimed at lay audiences was at the core of visibility in science communication during the PUS era (Peters, 2013; Schäfer et al., 2015). Peters (2013) asserted that scientists differentiated between internal scientific and public science communication: "This distinction has at least two aspects: the exclusion of the public from communication dealing with knowledge creation and validation, and the conceptualization of scientific knowledge as 'special knowledge'" (Peters, 2013, p. 14103). Thus, visibility was thought of as the visibility of scientific knowledge but not in its original form. The visibility of scientific knowledge in the news media requires a different form of presentation than in scientific publications. In addition, in the PUS paradigm, public visibility encompasses only scientific knowledge itself and not, at least not to the same extent, knowledge creation and validation (i.e., information about the scientific process). 
This changed with the advent of the PEST paradigm. It was acknowledged that merely conveying scientific information through the mass media or other formats of science communication was not sufficient for developing positive public attitudes and scientific literacy. Science communicators stressed dialogic and participatory activities beyond communication through the mass media. Bauer and Jensen (2011, p. 4) stated:

PE [Public Engagement] activities include a wide range of activities such as lecturing in public or in schools, giving interviews to journalists for newspapers, radio or television, writing popular science books, writing the odd article for newspapers or magazines oneself, taking part in public debates, volunteering as an expert for a consensus conference or a "café scientifique," collaborating with non-governmental organizations (NGOs) and associations as advisors or activists, and more.

Of course, many of these activities were already underway in the previously dominant PUS paradigm. Dialogue and participation, however, were now emphasized. Dialogic and participatory forms of science communication have been shown to increase the public's understanding of science as well as their critical abilities, interest in further scientific information, and perception of science as responsive (Schäfer et al., 2015).

This has consequences for visibility in science communication. First, as a result of public engagement, both scientific knowledge and its creation become visible to the general public via several venues, such as children's universities or science nights. In this paradigm, scientists can demonstrate theories and methods (e.g., experiments) in various formats, such as citizen science programs. Such programs allow the public to experience a scientific project, including the gathering of data and, ideally, their transformation into scientific knowledge. Second, the nature of scientists' public visibility has changed. They are still consulted as experts to disseminate scientific knowledge, but their work can be criticized, and their personal lives can also become visible (Schäfer \& Metag, 2021; Thompson, 2005). Therefore, the visibility of scientific knowledge, its creation, and scientists themselves are crucial in this paradigm.

\section{4 (In)visibility in science commu- nication in the new information environment}

Digitization and the new information environment have provided new opportunities for making scientific knowledge, the scientific process, and scientists visible (for an overview of the changes in knowledge systems, see Neuberger et al., 2019). The internet has engendered changes in the visibility and invisibility of scientists, scientific knowledge, and the scientific process. Therefore, we will now discuss the consequences of visibility in new information environments on scientific knowledge and scientists.

\subsection{The visibility of scientific knowledge in new information environments}

The channels and formats utilized to disseminate and access scientific knowledge have increased online. They include collaborative platforms, such as Wikipedia, online video platforms, such as YouTube, science blogs, and, of course, online academic journals. Regarding the visibility of scientific knowledge and its production, these new online formats must be evaluated against the criteria of the abovementioned definition of visibility, which entails availability, approval, and accessibility to third parties (Stohl et al., 2016). Online communication facilitates the availability of scientific knowledge and, occasionally, its production. Usually, scientists approve this availability.

The open science movement exemplifies the possibilities of new visibility through online communication. According to the movement, high visibility is desirable (Fecher \& Friesike, 2014). Increased visibility is achieved through transparency in the research process: showing 'science in the making'; preregistering projects in online databases; making the data, code, 
and other research materials available online; and publishing the results in open access journals (Klein et al., 2018). In addition, online citizen science projects can increase the visibility of scientific knowledge and its creation. The concept of citizen science implies public involvement in the research process, which can take several forms, from data collection through online gaming and citizen participation in the formulation of the research questions to development of the methods and analysis of the data (Kullenberg \& Kasperowski, 2016). Thus, scientific knowledge and the scientific process become more visible to citizen participants.

However, the visibility of scientific knowledge is not always the intention of scientists. Involuntary disclosure is also closely tied to digital media because it facilitates third-party information disclosure (Flyverbom et al., 2016). There is also always a certain degree of competition in science; consequently, scientists sometimes prefer not to disclose their research ideas, hypotheses, or findings to the public or other scientists, lest their ideas be stolen. Invisibility might be preferred for scientists and political actors when science becomes political and affects political actors and policy making (e.g., environmental policy; Lester \& Hutchins, 2012). In these cases, scientists or other actors do not approve third-party access to scientific knowledge.

The new information environment increases the risk of uncontrolled or unintentional visibility of scientists and scientific knowledge. In the digital world, controlling visibility is more difficult (Thompson, 2005). Scientific results can potentially be leaked before authors decide to publish them. Another potential pitfall is the strategic manipulation of results or out-of-context use, which can lead to public scandals (Thompson, 2005). One of the most notable examples is the Climategate scandal. The emails of the researchers working on climate change at a British university were hacked and taken out of context to create the impression that the researchers were manipulating their data (Bowe, Oshita, Terracina-Hartman, \& Chao, 2014).

Scientific conferences, which were formerly closed to the public, have been shaped by these developments. In recent years, scientists are increasingly using social media, usually Twitter, to post content from conferences (Bik \& Goldstein, 2013). This can include taking pictures of their peers' presentations and posting them. While some scientists enjoy keeping up to date by following a conference's hashtag, others are not comfortable seeing pictures of themselves or their unpublished results on social media. Accordingly, some conference organizers started using signs through which presenters can indicate whether or not pictures can be taken during their presentation (for an example, see the Social Media Guidelines for the World Marine Mammal Conference from 2019). Nevertheless, for scientists who do not have Twitter or other social media accounts, visibility on social media is hard to control: since they cannot be tagged by peers, they do not get notified when someone is making them or their findings visible on social media.

Another aspect of the tension between visibility and invisibility becomes apparent when the content of online scientific knowledge is considered. The digital media enable the dissemination of scientific information by anyone (Neuberger et al., 2019), thus increasing the amount of scientific knowledge available to the public. However, this also creates the possibility for the dissemination of misinformation (Scheufele \& Krause, 2019). This issue has been discussed in analyses of the online circulation of misinformation related to climate change and other environmental issues (Kaiser \& Rhomberg, 2015; Ladle, Jepson, \& Whittaker, 2005). Thus, although scientific knowledge becomes available and accessible for a broader audience online, the same holds true for misinformation.

Within the PUS paradigm, this creates tension because the basic idea is that the spread of scientifically correct information promotes positive public attitudes toward science. Since the effects of the dissemination of scientific misinformation are still 
unclear (Scheufele \& Krause, 2019), the societal consequences of scientific misinformation online need to be researched.

These examples demonstrate the possibility of the permeability or even collapse of the distinction between the visibility of scientific knowledge in the scientific system and its visibility to the general public in the digital information environment. What is visible to the scientific community could easily become visible to the general public. This highlights the first tension regarding visibility in science communication in a digital world: the tension between the increased visibility of scientific knowledge and its creation to lay audiences and the risk of information and data theft, manipulation, and out-of-context use.

The tension between visibility and invisibility in the digital world is also apparent in science journalism. Science journalists were traditionally responsible for making scientific knowledge and experts visible to the general public; however, their role has changed. Working conditions have worsened since the late 1990s and early 2000s. The 24-hour news cycle has created greater time pressures, and journalists have fewer resources (Schäfer, 2017a). Economic pressures are of great concern to traditional journalism in general. This is, however, exacerbated for science journalism, which, as a specialized field, is often regarded as expendable during difficult financial circumstances (Allan, 2011). This situation has led many media companies to shed staff and reduce or even close their science departments (Scheufele, 2013). One of the consequences could be a reduced visibility of scientific knowledge. The science journalist, the traditional intermediary through whom scientific knowledge became available and accessible to the general public, is less able to fulfill this function and, thus, to contribute to increasing the visibility of science.

The internet has certainly contributed to the economic problems of science journalism and thus, indirectly, to the potentially reduced visibility of scientific knowledge. However, it has also given science journalists new opportunities to make scientific knowledge visible to the broader public. Journalists can use online applications, particularly social media, to publish news about scientific findings, interact with their audiences about their work, and conduct research for their stories (Brumfiel, 2009; Schäfer, 2017a). Thus, the new information environment creates tension with regard to the visibility of the scientific knowledge disseminated through science journalism: on one hand, digital media is a factor in the demise of traditional science journalism, thus heightening the invisibility of scientific knowledge; on the other, it has created new possibilities for science journalists to make scientific knowledge visible to the broader public online.

\subsection{Visibility of scientists in new information environments}

The emergence of online media has created new tensions regarding the visibility of scientists. Studies on scientists' interactions with journalists and the mass media have repeatedly shown that public outreach and media contact have been common but not routine (Peters, 2013, 2019). In traditional media environments, interactions with journalists and the mass media has already created tensions among scientists. Most scientists believed that public outreach was necessary because of the potentially positive effects of external science communication (Peters, 2013). However, this outreach was not always appreciated by their colleagues and the scientific community (Rödder, 2014). There were concerns about the misinterpretation or misuse of scientific knowledge and journalists' failure to contact those scientists who, in the view of the scientific community, were the leading experts. Therefore, scientists who engaged in science communication to the broader public had to navigate these issues.

These tensions have been heightened in the PEST paradigm. For scientists, online communication increases the opportunities for visibility and direct contact with lay audiences (Brossard, 2013), and it can be used to combat misinformation (Scheufele \& Krause, 2019). The PEST paradigm encourages scientists to engage with the public through all possible 
formats, online formats being important among them. Scientists now have to decide whether to have a social media presence, present research projects on a website, or involve the public in projects via online citizen science activities. They also have to consider the potential pitfalls of this engagement, such as the misuse of scientific knowledge and public criticism (Lewis, Van Bavel, Somerville, \& Gruber, 2018).

At the same time, social media can also be a tool for fostering diversity in science communication by enhancing visibility. First, who becomes visible through social media is more diverse. For example, female scientists, who are still underrepresented in traditional news coverage (Chimba \& Kitzinger, 2010; González, Mateu, Pons, \& Domínguez, 2017), can use social media as a tool to gain visibility or for empowerment, as studies on protests of female scientists have shown (e.g., Brantner, Lobinger, \& Stehling, 2019). Second, visibility on social media can also enhance the diversity of how scientists are represented. While traditional news media usually depict scientists in a stereotypical way (e.g., sitting in front of a bookshelf or wearing a white coat; Christidou \& Kouvatas, 2013), scientists can make their own choices about how they would like to present themselves on their social media accounts, ranging from the use of an official picture provided by the university to personal pictures, avatars, or selfies (Jarreau et al., 2019).

Consequently, scientists must navigate the tension of creating visibility for themselves and their work more easily through online communication and the potential dangers of online visibility (e.g., reputational harm, misuse of scientific knowledge, and public criticism or even hostility). Thus, invisibility to the general public is sometimes preferable. This tension must be considered by science communicators (e.g., university press offices or policy makers) when encouraging scientists to communicate through the new digital tools and spaces (Rödder, 2014).

\section{Conclusion}

The goal of this article was to disentangle the concepts of visibility and invisibility in science communication. It conceptualized visible scientific knowledge as knowledge that is available, approved for dissemination, and made accessible. When conceptualizing the visibility of scientists, this article drew on the conceptualization of their exposure to others and the revelation of power structures in science. The article has highlighted the differences in the application of these definitions to scientific knowledge and on scientists as actors on the basis of their visibility in the scientific system and to the general public. Science communication research is concerned with both kinds of visibility, and discussing its dominant paradigms has highlighted changes in the importance of visibility and invisibility in science communication. While visibility to the general public was traditionally confined to the visibility of scientific knowledge, the PEST paradigm has led to increased focus on the visibility of knowledge creation.

The online environment offers many formats, spheres, and applications for making scientific knowledge, its creation, and scientists visible. Some of the tensions identified in this article cannot be attributed to the internet, at least not initially. However, most have been intensified by online communication. They can be condensed into three categories:

1. The tension regarding scientific knowledge and its creation refers to the relative ease of making scientific knowledge and its creation available to the general public through online communication. This comes with the risk of data theft, misuse, manipulation, or out-of-context use. Not only can scientifically correct information be manipulated, but scientific misinformation can also be disseminated.

2. Science journalists must deal with conflicting developments associated with the digital media environment. On one hand, the digital media is a factor in the demise of traditional science jour- 
nalism and the increased difficulties in making scientific knowledge visible in the public sphere that traditional mass media created. On the other hand, online communication has created new possibilities for science journalists to make scientific knowledge visible to the broader public.

3. Scientists face the tension of creating visibility for themselves and their work more easily through online communication and dealing with potential dangers and risks. Digital visibility provides opportunities for having direct contact with the general public, making research comprehensible or engaging in direct discussions, and combating misinformation. This comes with the risk of reputational damage and exposure to public criticism and even hostility.

This article focused on the definition of visibility in science communication, the information that becomes visible, the circumstances under which it does, and the shaping of this visibility by various actors. Thus, there is often an underlying notion of strategic communication. Visibility can certainly be used strategically. It relates to the notion of visibility management (Flyverbom et al., 2016). This is also the case in science communication as strategic communication is an important aspect. Universities have expanded their public affairs offices (Fähnrich, Metag, Post, \& Schäfer, 2019) to advance their strategic interests by communicating the scientific knowledge that is created at their institutions. Through this strategic management of visibility, institutions and scientists try to maintain or enhance their reputation, increase the public's understanding of and engagement with science, and gain other potential benefits, such as improving their chances of acquiring future funding.

Scholars have assumed that several of the abovementioned visibility strategies would increase the transparency of science and knowledge creation (Klein et al., 2018). Transparency is often regarded as an ideal state in which everything is visible (Ananny \& Crawford, 2018; Hood, 2006) or a state of absolute disclosure of all information (Albu \& Flyverbom, 2019). The desirability of this is debatable: increased visibility is not necessarily accompanied by a linear increase in transparency. Stohl et al. (2016, p. 131) formulated the "transparency paradox," which states that online communication and increased visibility can create information overload. The overwhelming amount of available information could enable actors to strategically conceal information in the endless amount of visible data. Because the amount of available information would be unmanageable for users, information could be visible but not transparent (Stohl et al., 2016). Potential examples of this strategy in science communication include making so many details about a research project available that the methodological problems are not apparent because a lot of information needs to be combined in the correct manner.

This article has also shown the limits of a strategic management of visibility. Especially online, visibility or invisibility can quickly become uncontrollable (Thompson, 2005). The concept of visibility in science communication is not confined to strategy. The aspects of scientific knowledge that are actually visible and invisible, how these should be determined from a science of science communication perspective, and how the scientific community, general public, and other audiences perceive the new visibility of scientists and scientific knowledge must be considered. With regard to public engagement with science, it is necessary to discuss the influence of the visibility and invisibility of scientific knowledge on the public's knowledge about and attitudes toward science as well as their trust in science and scientists (Schäfer, Füchslin, Metag, Kristiansen, \& Rauchfleisch, 2018).

\section{References}

Albu, O. B., \& Flyverbom, M. (2019). Organizational transparency: Conceptualizations, conditions, and consequences. Business \& Society, 58(2), 268-297. https://doi. org/10.1177/0007650316659851. 
Allan, S. (2011). Introduction: Science journalism in a digital age. Journalism, 12(7), 771-777. https://doi. org/10.1177/1464884911412688.

Ananny, M., \& Crawford, K. (2018). Seeing without knowing: Limitations of the transparency ideal and its application to algorithmic accountability. New Media \& Society, 20(3), 973-989. https://doi. org/10.1177/1461444816676645.

Bauer, M. W., \& Jensen, P. (2011). The mobilization of scientists for public engagement. Public Understanding of Science, 20(1), 3-11. https://doi. org/10.1177/0963662510394457.

Bik, H. M., \& Goldstein, M. C. (2013). An introduction to social media for scientists. PLoS Biology, 11(4), e1001535. https://doi. org/10.1371/journal.pbio.1001535.

Bonfadelli, H., Fähnrich, B., Lüthje, C., Milde, J., Rhomberg, M., \& Schäfer, M. S. (Eds.) (2017). Forschungsfeld Wissenschaftskommunikation [Research field science communication]. Wiesbaden: Springer VS.

Bourguignon, J.-P. (2017, April 18). Scientists, power, and the power of scientists. Simon Initiative Distinguished Lecture, Carnegie Mellon University, Pittsburgh, USA. Retrieved from https: / /erc.europa.eu/news / scientists-power-and-power-scientists.

Bowe, B. J., Oshita, T., Terracina-Hartman, C., \& Chao, W.-C. (2014). Framing of climate change in newspaper coverage of the East Anglia e-mail scandal. Public Understanding of Science, 23(2), 157-169. https://doi. org/10.1177/0963662512449949.

Bowman, N. D., \& Keene, J. R. (2018). A layered framework for considering open science practices. Communication Research Reports, 35(4), 363-372. https://doi.org/10.10 80/08824096.2018.1513273.

Brantner, C., \& Huber, B. (2013). How visible is communication studies? Press coverage of the discipline in three German-language quality newspapers. Studies in Communication | Media, 2(2), 247-264. https://doi. org/10.5771/2192-4007-2013-2-247.

Brantner, C., Lobinger, K., \& Stehling, M. (2019). Memes against sexism? A multi-method analysis of the feminist protest hashtag \#distractinglysexy and its resonance in the mainstream news media. Convergence: The International Journal of Research into New
Media Technologies, 3(7), 674-696. https:// doi.org/10.1177/1354856519827804.

Brossard, D. (2013). New media landscapes and the science information consumer. Proceedings of the National Academy of Sciences of the United States of America, 110 Suppl 3, 14096-14101. https://doi. org/10.1073/pnas.1212744110.

Brumfiel, G. (2009). Science journalism: Supplanting the old media? Nature, 458, 274-277.

Bucchi, M. (2008). Of deficits, deviations and dialogues: Theories of public communication of science. In M. Bucchi \& B. Trench (Eds.), Routledge international handbooks: Handbook of public communication of science and technology (pp. 57-76). London, New York: Routledge.

Chimba, M., \& Kitzinger, J. (2010). Bimbo or boffin? Women in science: An analysis of media representations and how female scientists negotiate cultural contradictions. Public Understanding of Science, 19(5), 609-624. https://doi. org/10.1177/0963662508098580.

Christidou, V., \& Kouvatas, A. (2013). Visual self-images of scientists and science in Greece. Public Understanding of Science, 22(1), 91-109. https://doi. org/10.1177/0963662510397118.

Cruz, J. M. (2017). Invisibility and visibility in alternative organizing: A communicative and cultural model. Management Communication Quarterly, 31(4), 614-639. https:// doi.org/10.1177/0893318917725202.

Dahlberg, L. (2018). Visibility and the public sphere: A normative conceptualisation. Javnost - the Public, 25(1-2), 35-42. https://doi.org/10.1080/13183222.2018.1 418818.

Dernbach, B. (2012). Vom Elfenbeinturm ins Rampenlicht [From the ivory tower into the spotlight]. Wiesbaden: VS Verlag für Sozialwissenschaften. https://doi. org/10.1007/978-3-531-94123-3.

Donk, A. (2011). Ambivalenzen der Digitalisierung: Neue Kommunikations- und Medientechnologien in der Wissenschaft [Ambivalences of digitization: New information and communication technologies in science] [Doctoral dissertation, University of Münster]. Münster: MV Wissenschaft. Retrieved from https:// 
repositorium.uni-muenster.de/.document/miami/277c75ef-7878-40c7-a376ba978ea72438/diss-donk-buchblock.pdf.

Dunwoody, S. (2014). Science journalism: Prospects in the digital age. In M. Bucchi \& B. Trench (Eds.), Routledge international handbooks: Routledge handbook of public communication of science and technology (2nd ed., pp. 27-39). London: Routledge. https://doi.org/10.4324/9780203483794. ch3.

Durant, J. (2010). Public understanding of science. In S. Priest (Ed.), Encyclopedia of science and technology communication. Thousand Oaks, California: Sage. https:// doi.org/10.4135/9781412959216.n213.

Eisenegger, M. (2005). Reputation in der Mediengesellschaft: Konstitution - Issues Monitoring - Issues Management [Reputation in the media society: Constitution - issues monitoring - issues management]. Wiesbaden: Springer Fachmedien.

Fähnrich, B., Metag, J., Post, S., \& Schäfer, M. S. (Eds.) (2019). Forschungsfeld Hochschulkommunikation [Research field university education]. Wiesbaden: Springer VS. https://doi.org/10.1007/978-3-658-224097.

Fecher, B., \& Friesike, S. (2014). Open science: One term, five schools of thought. In S. Friesike \& S. Bartling (Eds.), Opening science: The evolving guide on how the internet is changing research, collaboration and scholarly publishing (Vol. 9, pp. 17-47). Wiesbaden: Springer. https:// doi.org/10.1007/978-3-319-00026-8_2.

Felt, U. (2000). Why should the public "understand" science? A historical perspective on aspects of the public understanding of science. In M. Dierkes \& C. von Grote (Eds.), Between understanding and trust: The public, science and technology (pp. 7-38). Amsterdam: Harwood Academic Publishers.

Felt, U., \& Fochler, M. (2012). Re-ordering epistemic living spaces: On the tacit governance effects of the public communication of science. In S. Rödder (Ed.), Sociology of the sciences yearbook: Vol. 28. The sciences' media connection: Public communication and its repercussions (pp. 133154). Dordrecht: Springer. https://doi. org/10.1007/978-94-007-2085-5_7.
Flyverbom, M., Leonardi, P., Stohl, C., \& Stohl, M. (2016). Digital age: The management of visibilities in the digital age - Introduction. International Journal of Communication, 10, 98-109. Retrieved from https://ijoc.org/index.php/ijoc/article/ download/4841/1532.

Funck, A. (2015). Die transparente Redaktion: Ein Ansatz für die strategische Öffentlichkeitsarbeit von Zeitungsverlagen [The transparent news room: An approach for strategic public communication of newspaper publishers]. Wiesbaden: Springer Fachmedien Wiesbaden.

Gerhards, J., \& Schäfer, M. S. (2009). Two normative models of science in the public sphere: Human genome sequencing in German and US mass media. Public Understanding of Science, 18(4), 437-451. https://doi. org/10.1177/0963662507082891.

González, D., Mateu, A., Pons, E., \& Domínguez, M. (2017). Women scientists as decor: The image of scientists in Spanish press pictures. Science Communication, 39(4), 535-547. https://doi. org/10.1177/1075547017719074.

Grundmann, R. (2017). The problem of expertise in knowledge societies. Minerva, 55(1), 25-48. https://doi.org/10.1007/s11024016-9308-7.

Hood, C. (2006). Transparency in historical perspective. In C. Hood \& D. Heald (Eds.), Proceedings of the British Academy: Vol. 135. Transparency: The key to better governance? (pp. 3-23). Oxford: Oxford University Press.

Horst, M. (2013). A field of expertise, the organization, or science itself? Scientists' perception of representing research in public communication. Science Communication, 35(6), 758-779. https://doi. org/10.1177/1075547013487513.

Huber, B. (2014). Öffentliche Experten: Über die Medienpräsenz von Fachleuten [Public experts: On the media presence of experts]. Wiesbaden: Springer VS.

Jarreau, P. B., Cancellare, I. A., Carmichael, B. J., Porter, L., Toker, D., \& Yammine, S. Z. (2019). Using selfies to challenge public stereotypes of scientists. PloS One, 14(5), e0216625. https://doi.org/10.1371/journal.pone.0216625. 
Jensen, P. (2011). A statistical picture of popularization activities and their evolutions in France. Public Understanding of Science, 20(1), 26-36. https://doi. org/10.1177/0963662510383632.

Jonkman, J. G. F., Trilling, D., Verhoeven, P., \& Vliegenthart, R. (2020). To pass or not to pass: How corporate characteristics affect corporate visibility and tone in company news coverage. Journalism Studies, 21(1), 1-18. https://doi.org/10.1080/146167 0X.2019.1612266.

Kaiser, J., \& Rhomberg, M. (2015). Questioning the doubt: Climate skepticism in German newspaper reporting on COP17. Environmental Communication, 10(5), 556-574. https://doi.org/10.1080/17524032.2015.1 050435.

Klein, O., Hardwicke, T. E., Aust, F., Breuer, J., Danielsson, H., Hofelich Mohr, A., ... . Frank, M. C. (2018). A practical guide for transparency in psychological science. Collabra: Psychology, 4(1), 20. https://doi. org/10.1525/collabra.158.

Kullenberg, C., \& Kasperowski, D. (2016). What is citizen science? A scientometric meta-analysis. PloS One, 11(1), e0147152. https://doi.org/10.1371/journal. pone.0147152.

Ladle, R. J., Jepson, P., \&Whittaker, R. J. (2005). Scientists and the media: The struggle for legitimacy in climate change and conservation science. Interdisciplinary Science Reviews, 30(3), 231-240. https://doi. org/10.1179/030801805X42036.

Lehmkuhl, M., \& Leidecker-Sandmann, M. (2019). "Visible scientists revisited": Zum Zusammenhang von wissenschaftlicher Reputation und der Präsenz wissenschaftlicher Experten in der Medienberichterstattung über Infektionskrankheiten [On the connection between scientific reputation and the presence of scientific experts in media coverage of infectious diseases]. Publizistik, 64(4), 479-502. https://doi. org/10.1007/s11616-019-00530-1.

Leonardi, P. M. (2014). Social media, knowledge sharing, and innovation: Toward a theory of communication visibility. Information Systems Research, 25(4), 796-816. https:// doi.org/10.1287/isre.2014.0536.

Lester, L., \& Hutchins, B. (2012). The power of the unseen: Environmental conflict, the media and invisibility. Media, Culture \& Society, 34(7), 847-863. https://doi. org/10.1177/0163443712452772.

Lewis, N. A., Jr., Van Bavel, J. J., Somerville, L. H., \& Gruber, J. (2018, November 5). A social media survival guide for scientists. Science [Online]. https://doi.org/10.1126/ science.caredit.aav9607.

Merton, R. K. (1968). The Matthew effect in science: The reward and communication systems of science are considered. Science, 159(3810), 56-63. https://doi.org/10.1126/ science.159.3810.56.

Miller, J. D. (1983). Scientific literacy: A conceptual and empirical review. Daedalus, 112(2), 29-48. Retrieved from http: / /www. jstor.org/stable/20024852.

Neuberger, C. (2014). Social media in der Wissenschaftsöffentlichkeit: Forschungsstand und Empfehlungen [Social media in the scientific public sphere: State of research and recommendations]. In P. Weingart \& P. Schulz (Eds.), Wissen - Nachricht-Sensation: Zur Kommunikation zwischen Wissenschaft, Öffentlichkeit und Medien [Knowledge-Message-Sensation: On the communication between science, public sphere and media] (pp. 315-36). Weilerswist: Velbrück.

Neuberger, C., Bartsch, A., Reinemann, C., Fröhlich, R., Hanitzsch, T., \& Schindler, J. (2019). Der digitale Wandel der Wissensordnung: Theorierahmen für die Analyse von Wahrheit, Wissen und Rationalität in der öffentlichen Kommunikation [The digital transformation of knowledge systems: A theoretical framework for analysing truth, knowledge and rationality in public communication]. Medien \& Kommunikationswissenschaft, 67(2), 167-186. https:// doi.org/10.5771/1615-634X-2019-2-167.

Nölleke, D. (2013). Experten im Journalismus: Systemtheoretischer Entwurf und empirische Bestandsaufnahme [Experts in journalism: System theory approach and empirical assessment]. Baden-Baden: Nomos.

Nosek, B. A., Alter, G., Banks, G. C., Borsboom, D., Bowman, S. D., Breckler, S. J., . . . Yarkoni, T. (2015). Scientific standards: Promoting an open research culture. Science, 348(6242), 1422-1425. https://doi. org/10.1126/science.aab2374. 
Open Science Collaboration (2015). Psychology: Estimating the reproducibility of psychological science. Science, 349(6251), aac4716. https://doi.org/10.1126/science. aac4716.

Peters, H. P. (2013). Gap between science and media revisited: Scientists as public communicators. Proceedings of the National Academy of Sciences of the United States of America, 110 Suppl 3, 14102-14109. https://doi.org/10.1073/pnas.1212745110.

Peters, H. P. (2019). WissenschaftlerInnen als Kommunikatoren [Scientists as communicators]. In B. Fähnrich, J. Metag, S. Post, \& M. S. Schäfer (Eds.), Forschungsfeld Hochschulkommunikation [Research field university communication] (pp. 209-225). Wiesbaden: Springer VS. https://doi. org/10.1007/978-3-658-22409-7_10.

Petersen, A. M., Fortunato, S., Pan, R. K., Kaski, K., Penner, O., Rungi, A., . . Pammolli, F. (2014). Reputation and impact in academic careers. Proceedings of the National Academy of Sciences of the United States of America, 111(43), 15316-15321. https:// doi.org/10.1073/pnas.1323111111.

Rödder, S. (2014). Die Rolle sichtbarer Wissenschaftler in der Wissenschaftskommunikation [The role of visible scientists in science communication]. In P. Weingart \& P. Schulz (Eds.), Wissen - Nachricht-Sensation. Zur Kommunikation zwischen Wissenschaft, Öffentlichkeit und Medien [Knowledge-Message-Sensation: On the communication between science, public sphere and media] (pp. 46-70). Weilerswist: Velbrück Wissenschaft.

Schäfer, M. S. (2017a). How changing media structures are affecting science news coverage. In K. H. Jamieson, D. M. Kahan, \& D. A. Scheufele (Eds.), Oxford library of psychology: The Oxford handbook on the science of science communication (pp. 51-57). New York, NY: Oxford University Press.

Schäfer, M. S. (2017b). Wissenschaftskommunikation Online [Science communication online]. In H. Bonfadelli, B. Fähnrich, C. Lüthje, J. Milde, M. Rhomberg, \& M. S. Schäfer (Eds.), Forschungsfeld Wissenschaftskommunikation [Research field science communication] (pp. 275-293). Wiesbaden: Springer VS.
Schäfer, M. S., Füchslin, T., Metag, J., Kristiansen, S., \& Rauchfleisch, A. (2018). The different audiences of science communication: A segmentation analysis of the Swiss population's perceptions of science and their information and media use patterns. Public Understanding of Science, 27(7), 836-856. https://doi. org/10.1177/0963662517752886.

Schäfer, M. S., Kristiansen, S., \& Bonfadelli, H. (2015). Wissenschaftskommunikation im Wandel: Relevanz, Entwicklung und Herausforderungen des Forschungsfeldes [Changing science communication: Relevance, development and challenges of the research field]. In M. S. Schäfer, S. Kristiansen, \& H. Bonfadelli (Eds.), Wissenschaftskommunikation im Wandel [Changing science communication] (pp. 10-42). Köln: Herbert von Halem Verlag.

Schäfer, M. S., \& Metag, J. (2021). Audiences of science communication between pluralisation, fragmentation and polarisation. In M. Bucchi \& B. Trench (Eds.), Routledge handbook of public communication of science and technology ( $3^{\text {rd }}$ ed., pp. 291-304). Abingdon: Routledge.

Schaffer, J. (2019). Sichtbarkeit: Epistemologie und Politik eines Schlüsselbegriffs analoger und digitaler Medienrealitäten [Visibility: Epistemology and politics of a key concept of analog and digital media realities]. In J. Dorer, B. Geiger, B. Hipfl, \& V. Ratković (Eds.), Handbuch Medien und Geschlecht [Handbook media and gender] (pp. 1-12). Wiesbaden: Springer VS. https://doi. org/10.1007/978-3-658-20712-0_8-1.

Scheufele, D. A. (2013). Communicating science in social settings. Proceedings of the National Academy of Sciences of the United States of America, 110 Suppl 3, 14040-14047. https://doi.org/10.1073/ pnas. 1213275110.

Scheufele, D. A., \& Krause, N. M. (2019). Science audiences, misinformation, and fake news. Proceedings of the National Academy of Sciences of the United States of America, 116(16), 7662-7669. https://doi. org/10.1073/pnas.1805871115.

Scott, C. (2013). Anonymous agencies, backstreet businesses, and covert collectives: Rethinking organizations in the $21^{\text {st }}$ century. Palo Alto: Stanford University Press. Re- 
trieved from http://gbv.eblib.com/patron/ FullRecord.aspx?p=1135733.

Stohl, C., Stohl, M., \& Leonardi, P. M. (2016). Managing opacity: Information visibility and the paradox of transparency in the digital age. International Journal of Communication Systems, 10, 123-137.

Thompson, J. B. (2005). The new visibility. Theory, Culture \& Society, 22(6), 31-51.

Vogler, D., \& Post, S. (2019). Reputation von Hochschulen [Universities' reputation]. In B. Fähnrich, J. Metag, S. Post, \& M. S. Schäfer (Eds.), Forschungsfeld Hochschulkommunikation [Research field university communication] (pp. 319-340). Wiesbaden: Springer VS. https://doi. org/10.1007/978-3-658-22409-7_15.
Wenninger, A., Weingart, P., \& Wormer, P. (2017). Social media and digital science communication: Analysis and recommendations for dealing with risks and opportunities in a democracy. Munich: acatech - National Academy of Science and Engineering, German National Academy of Sciences Leopoldina, Union of the German Academies of Sciences and Humanities. Retrieved from https://www.acatech.de/wp-content/uploads/2018/03/WOM2_EN_web_ final.pdf.

World Marine Mammal Conference (2019, n. d.). Social media guidelines. Retrieved from https://www.wmmconference.org/ social-media-guidelines/. 